\title{
Thermal sensitivity of mitochondrial function in the Antarctic Notothenioid Lepidonotothen nudifrons
}

Accepted: 2 September 1999

\begin{abstract}
The thermal sensitivity of mitochondrial function was investigated in the stenothermal Antarctic fish Lepidonotothen nudifrons. State 3 respiration increases with increasing temperature between $0{ }^{\circ} \mathrm{C}$ and $18^{\circ} \mathrm{C}$ with a $Q_{10}$ of $2.43-2.63$. State 4 respiration in the presence of oligomycin, an inhibitor of mitochondrial ATP synthase, quantifies the leakage of protons through the inner mitochondrial membrane, which causes oxygen consumption without concomitant ATP production. This parameter shows an unusually high $Q_{10}$ of $4.21 \pm 0.42\left(0-18{ }^{\circ} \mathrm{C}\right)$, which indicates that proton leakage does not depend merely on ion diffusion but is an enzyme-catalysed process. The differential thermal sensitivity of oxidative phosphorylation $(=$ state 3$)$ and proton leakage ( $=$ state 4 in the presence of oligomycin) leads to progressive uncoupling of the mitochondria and decreased efficiency of oxidative phosphorylation under in vivo conditions if the body temperature of L. nudifrons increases.
\end{abstract}

Key words Antarctic fish · Temperature · Mitochondrial respiration $\cdot$ Proton leakage $\cdot$ Isocitrate dehydrogenase

I. Hardewig · H.O. Pörtner

Alfred Wegener Institute for Polar and Marine Research, Biology I/Ecophysiology, Columbusstrasse,

D-27568 Bremerhaven, Germany

L.S. Peck

British Antarctic Survey,

Cambridge CB3 OET, UK

I. Hardewig $(\square)$

Institute of Freshwater Ecology and Inland Fisheries,

Department of Biology and Ecology of Fishes,

Müggelseedamm 310,

D-12587 Berlin, Germany

e-mail: hardewig@igb-berlin.de

Tel.: + 49-030-64181614; Fax: +49-030-64181750

\section{Introduction}

The Antarctic marine fauna is constantly exposed to extremely low temperatures only ranging between $-1.8^{\circ} \mathrm{C}$ and $1{ }^{\circ} \mathrm{C}$. Organisms inhabiting the extreme Antarctic environment must have developed special physiological adaptations to overcome the adverse effects of low temperatures on metabolism.

Despite uncompensated low resting metabolic rates (Clarke 1991), polar animals show a compensatory increase in tissue oxidative capacity (van Dijk et al. 1998), which is reflected in higher mitochondrial densities compared to temperate zone animals (Archer and Johnston 1991; Johnston et al. 1998). Accordingly, some oxidative enzymes show 1.5 to 5-fold increased maximal activities in Antarctic fish tissues (Crockett and Sidell 1990). Cold adaptation may provoke a rise in oxidative capacity by enhancing the mitochondrial density or also by increasing the capacity of the individual mitochondrion. Johnston and co-workers (Johnston et al. 1994; Johnston et al. 1998) carried out an interspecies comparison of mitochondria from fishes of different latitudinal origin. They found that maximal respiration rates of mitochondria from Antarctic species at $-1{ }^{\circ} \mathrm{C}$ were close to those expected from extrapolation of the rates obtained in temperate species, suggesting only modest or no compensatory increase in respiratory capacity.

The physiological adaptation to the Antarctic environment seems to go along with reduced tolerance towards higher temperatures. All Antarctic organisms show strong stenothermality. Upper lethal temperatures as low as $4.5^{\circ} \mathrm{C}$ have been observed in the Antarctic brachiopod Liothyrella uva (Peck 1989). Different species of Trematomus die at temperatures between $5-6{ }^{\circ} \mathrm{C}$ (Somero and de Vries 1967), while the Antarctic eelpout Pachycara brachycephalum survives temperatures of up to $10{ }^{\circ} \mathrm{C}$ (van Dijk et al. 1999).

In a variety of marine species, exposure to critically high temperatures causes the formation of anaerobic 
mitochondrial endproducts which may characterise the lethal limits (Sommer et al. 1997). In Antarctic invertebrates, temperature-induced accumulation of anaerobic end-products has been observed at temperatures only slightly above their habitat temperature: at $2{ }^{\circ} \mathrm{C}$ in the clam Limopsis marionensis (Pörtner et al. 1999a) and between $3{ }^{\circ} \mathrm{C}$ and $6{ }^{\circ} \mathrm{C}$ in Laternula elliptica (H.O. Pörtner, I. Hardewig, L. Peck, in preparation). Only one study so far has determined the critical temperature in an Antarctic vertebrate. The Antarctic eelpout Pachycara brachycephalum only accumulates succinate at a temperature of $10{ }^{\circ} \mathrm{C}$ (van Dijk et al. 1999) which may indicate that Antarctic vertebrates are more tolerant towards higher temperatures than invertebrates.

The onset of anaerobic energy production suggests that oxidative, thus mitochondrial, energy provision is restrained at high temperatures. Thermal limitations of oxidative metabolism may be due to reduced oxygen provision through the ventilatory and circulatory system, or to the impairment of mitochondrial function. The present study was part of a larger investigation to analyse the effect of temperature increase on mitochondrial respiration of stenothermal Antarctic organisms. Parallel studies were carried out on the clam Laternula elliptica (Pörtner et al. 1999b) and the Nototheniod Lepidonotothen nudifrons (this study) in order to compare the thermal sensitivity of vertebrate and invertebrate mitochondria and to reveal a possible correlation between thermal sensitivity of the mitochondria and the critical temperature of the whole organism.

The benthic, moderately active Notothenioid L. nudifrons is endemic to the Southern ocean where water temperatures remain at about $0{ }^{\circ} \mathrm{C}$ all year round. While this investigation was in progress, Weinstein and Somero (1998) published a study regarding temperature effects on mitochondria of the Antarctic Notothenioid Trematomus bernacchii. They found that mitochondrial respiration is impaired at temperature above $18{ }^{\circ} \mathrm{C}$, which is beyond the lethal temperature limit of this species. Our data will be discussed with respect to these results.

\section{Materials and methods}

Animals

L. nudifrons were caught by scuba diving at Adelaide Island, Antarctica at a depth of 15-30 m in December 1997. Fish with a mean weight of $24.3 \pm 8.4 \mathrm{~g}$ were kept in aquaria with continuously running sea water at $0{ }^{\circ} \mathrm{C}$ for at least 1 week prior to experimentation. Experiments were conducted at Rothera Base (Antarctica).

Determination of ventilation rate and lethal temperature

Fish were incubated in a thermostatically controlled aquarium at $0{ }^{\circ} \mathrm{C}$. The water temperature was increased by $1{ }^{\circ} \mathrm{C} \mathrm{day}{ }^{-1}$. Ventilation rates were determined at the end of the acclimation period by counting the movements of the opercula of each individual fish over several minutes.

\section{Isolation of mitochondria}

The fish were killed by decapitation after slight anaesthetisation with MS $222\left(0.3 \mathrm{~g}^{-1}\right)$. Immediately after this, approximately $1 \mathrm{~g}$ liver tissue was removed, chopped finely with scissors in an ice-cold petri dish, and extracted in $30 \mathrm{ml}$ isolation buffer $(50 \mathrm{mM}$ Hepes pH 7.1 at $20^{\circ} \mathrm{C}, 85 \mathrm{mM} \mathrm{KCl}, 80 \mathrm{mM}$ sucrose, $5 \mathrm{mM}$ EDTA, $5 \mathrm{mM}$ EGTA. $1 \%$ BSA, $1 \mu \mathrm{g} \mathrm{ml}^{-1}$ aprotinin) with a Potter-Elvejhem homogeniser. The tissue was dispersed by three passes of a loose-fitting pestle. After centrifugation $(12 \mathrm{~min}$ at $300 \mathrm{~g})$ the pellet was re-homogenised in $30 \mathrm{ml}$ isolation buffer and centrifuged again. The combined supernatants were spun at $9500 \mathrm{~g}$ for $8 \mathrm{~min}$. The mitochondrial pellet was re-suspended in $1-1.5 \mathrm{ml}$ assay medium $\left(50 \mathrm{mM}\right.$ Hepes $\mathrm{pH} 7.1$ at $20{ }^{\circ} \mathrm{C}, 85 \mathrm{mM} \mathrm{KCl}, 80 \mathrm{mM}$

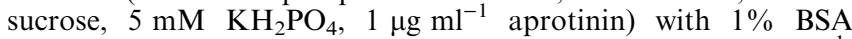
yielding a concentration of $15-20 \mathrm{mg}$ mitochondrial protein $\mathrm{ml}^{-1}$. The homogenate was kept at $0{ }^{\circ} \mathrm{C}$ during the isolation procedure.

\section{Mitochondrial respiration}

Oxygen consumption was measured at different temperatures using a Clarke-type oxygen electrode in a thermostatically controlled

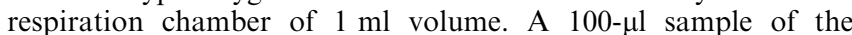
mitochondrial suspension (1.5-2 mg mitochondrial protein) was added to $0.9 \mathrm{ml}$ assay medium containing $5 \mu \mathrm{M}$ Ap $5 \mathrm{~A}$, an inhibitor of myokinase and $3.3 \mathrm{mM}$ succinate or $3.2 \mathrm{mM}$ pyruvate together with $0.5 \mathrm{mM}$ malate as substrates. $\Delta \mathrm{pH} / \Delta \mathrm{T}$ of the assay medium was -0.015 units ${ }^{\circ} \mathrm{C}^{-1}$ which is in accordance with $\alpha$-stat $\mathrm{pH}$ regulation. State 3 respiration was recorded after the addition of $0.3 \mathrm{mM}$ ADP. During state 3 respiration in the presence of succinate, $8 \mu \mathrm{M}$ rotenone was added to inhibit complex I. After all ADP had been phosphorylated state 4 respiration was determined. Finally, oligomycin, an inhibitor of mitochondrial ATP synthase, was added to a concentration of $2 \mu \mathrm{g} \mathrm{ml}^{-1}\left(1-1.3 \mu \mathrm{g} \mathrm{mg}^{-1}\right.$ mitochondrial protein) and oxygen consumption (state $4_{o l}$ ) was recorded for another $5 \mathrm{~min}$. After this time respiration rates tended to rise, probably caused by a progressive increase in membrane potential due to inhibition of the ATP synthase (see below).

In order to determine the effective $\mathrm{P} / \mathrm{O}$ ratios of oxidative phosphorylation, ATP production was measured during state 3 respiration in the presence of succinate without rotenone. Samples of $10 \mu \mathrm{l}$ assay medium were withdrawn from the respirometer during each run at defined time points. Samples were diluted in $990 \mu \mathrm{l}$ buffer $(0.2 \mathrm{M}$ Tris-acetate $\mathrm{pH} 7.75,1 \mathrm{mM}$ EDTA) and heated briefly to $95^{\circ} \mathrm{C}$ to inhibit mitochondrial function. ATP concentrations were determined luminometrically with an ATP assay kit (BioOrbit, Finland) following the rationale of Wibom et al. (1990). Effective P/O ratios were calculated as rate of ATP production divided by respiration rate.

Oxygen solubility in the assay medium at different temperatures was adopted from Johnston et al. (1994). Protein concentration of the mitochondrial pellet was determined by the Biuret method, using $5 \%$ deoxycholate to solubilise membrane proteins.

\section{Enzyme assay}

$\mathrm{NADP}^{+}$-dependent isocitrate dehydrogenase activity was determined in the mitochondrial suspension after Alp et al. (1976) with slight modifications. Mitochondria were lysed by the addition of $5 \%$ deoxycholate. The assay contained $70 \mathrm{mM}$ Tris- $\mathrm{HCl} \mathrm{pH} 7.1$, $8 \mathrm{mM} \mathrm{MgSO}_{4}, 2.5 \mathrm{mM} \mathrm{NADP}{ }^{+}, 1 \mathrm{mM} \mathrm{MnCl}, 3 \mathrm{mM}$ D/L-isocitrate and $20 \mathrm{mM}$ citrate. Enzyme activity was measured following the appearance of NADPH at $339 \mathrm{~nm}$ in a thermostatically controlled spectrophotometer at $0,4.5,9,15,21,25$ and $30^{\circ} \mathrm{C}$.

\section{Statistics}

All values are given as mean \pm standard deviation, $n=5$ for mitochondrial respiration experiments and $n=4$ for enzyme activities. Statistical significance was tested at the $P \leq 0.05$ level using 
analysis of variance (ANOVA) and Fisher's protected least squares differences (LSD). The Arrhenius break temperature of isocitrate dehydrogenase (IDH) was determined according to a method of Yaeger and Ultsch (1989) followed by an analysis of covariance (ANCOVA).

\section{Results}

Lethal temperature and ventilation rate

L. nudifrons showed a slight increase in ventilation frequency with temperature over the range of $0-7{ }^{\circ} \mathrm{C}$ (Fig. 1). At higher temperatures ventilation rates remained constant and three out of five fish died at 8$9{ }^{\circ} \mathrm{C}$. One individual showed exceptionally high ventilation rates (filled dots in Fig. 1), and a strong increase with temperature. This fish was least heat sensitive and survived temperatures of up to $11^{\circ} \mathrm{C}$.

Thermal sensitivity of mitochondrial respiration

The liver mitochondria of L. nudifrons were highly coupled at $0{ }^{\circ} \mathrm{C}$ with a respiratory control ratio $\left(\mathrm{RCR}_{\mathrm{ol}}\right.$ state 4 respiration determined in the presence of oligomycin) of $11.3 \pm 0.6$. The traditional RCR (state 4 determined without oligomycin) was found to be only slightly lower than $\mathrm{RCR}_{\mathrm{ol}}(10.1 \pm 1.1)$.

Maximal oxidative capacity in the presence of succinate was $3.68 \pm 1.19 \mathrm{nmol} \mathrm{O} \mathrm{min}^{-1} \mathrm{mg}^{-1}$ mitochondrial protein at $0{ }^{\circ} \mathrm{C}$. Addition of rotenone to inhibit complex I reduced oxygen consumption to $1.83 \pm 0.42 \mathrm{nmol} \mathrm{O} \mathrm{min}^{-1} \mathrm{mg}^{-1}$ mitochondrial protein indicating that complex I contributes to the oxidation of succinate (Fig. 2). Succinate is oxidised by succinate dehydrogenase and it is likely that the resulting fumarate enters the citric acid cycle delivering electrons to complex I. Therefore, state 3 respiration comprises part of

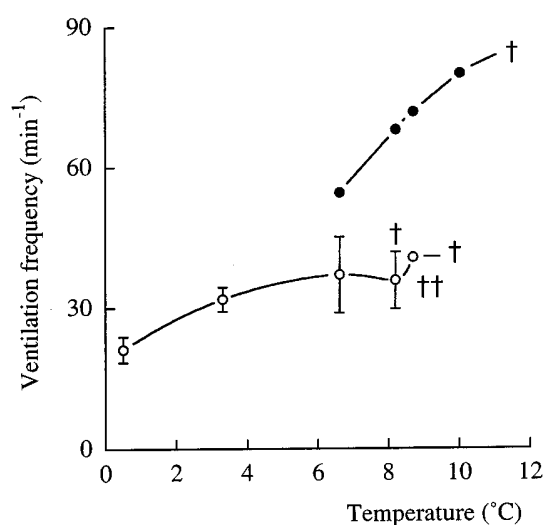

Fig. 1 Ventilation rate and mortality of Lepidonotothen nudifrons during exposure to elevated temperatures. One individual showed much higher ventilation rates than the other animals. Data from this fish are shown as filled circles. $\dagger$ denotes death of an animal. (Means $\pm \mathrm{SD}, n=4$ for open symbols)

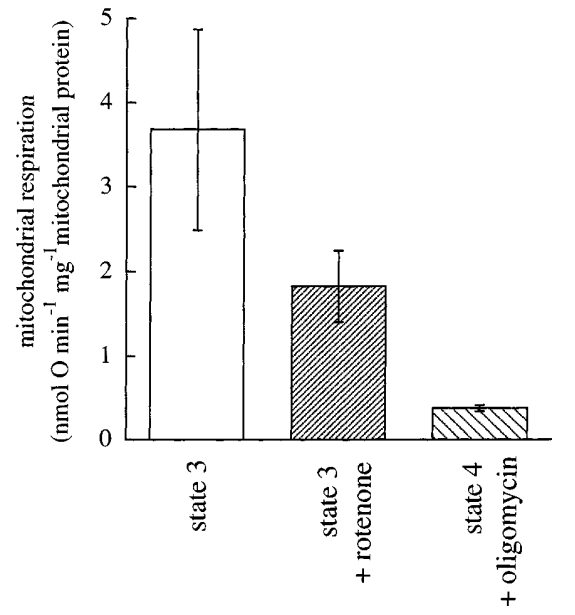

Fig. 2 Rates of state 3 and state 4 respiration (in the presence of oligomycin state $4_{\mathrm{ol}}$ ) of liver mitochondria from L. nudifrons at $0{ }^{\circ} \mathrm{C}$. Mitochondria respired on $3.3 \mathrm{mM}$ succinate as substrate. (Means $\pm \mathrm{SD}, n=5$ )

the citric acid cycle and the electron transport chain, while state 3 respiration in the presence of rotenone only represents electron transport through complex II-IV. Maximal oxidative capacity with malate and pyruvate as substrates was $2.28-2.40 \mathrm{nmol} \mathrm{O} \mathrm{min}{ }^{-1} \mathrm{mg}^{-1}$ mitochondrial protein $(n=2$, data not shown).

State 4 respiration in the presence of oligomycin (an inhibitor of mitochondrial ATP synthase) represents oxygen consumption due to proton leakage through the inner mitochondrial membrane, which amounted to $10.3 \%$ of state 3 respiration at $0{ }^{\circ} \mathrm{C}$ (Fig. 2). The addition of oligomycin had only a slight or no inhibitory effect on state 4 respiration, indicating that phosphorylation was minimal during state 4 .

State 3 respiration increased with increasing temperature between $0{ }^{\circ} \mathrm{C}$ and $18{ }^{\circ} \mathrm{C}$. For the sake of clarity, Fig. 3a shows the relative changes in respiration rates. State 3 respiration with and without rotenone showed similar $Q_{10}$ values of $2.63 \pm 0.35$ and $2.43 \pm 0.26$, respectively (Table 1 ). Proton leakage was more temperature sensitive with a significantly higher $Q_{10}$ of $4.21 \pm 0.46$. Arrhenius plots of respiration rates are linear and do not show breaks within the investigated temperature range (see Fig. 3b). Arrhenius activation energies $\left(E_{\mathrm{a}}\right)$ of mitochondrial respiration, which represent the temperature dependence of respiration rates, show the same trend as the $Q_{10}$ values (see Table 1).

The differential thermal sensitivity of proton leakage and state 3 respiration led to a progressive uncoupling of the mitochondria at higher temperatures. $\mathrm{RCR}_{\mathrm{ol}}$ values (state 3 state $4+$ oligomycin) decreased linearly at temperatures above $3{ }^{\circ} \mathrm{C}$ and fell from $11.29 \pm 0.58$ at $0{ }^{\circ} \mathrm{C}$ to $4.22 \pm 0.78$ at $18{ }^{\circ} \mathrm{C}$ (Fig. $4 a$ ). Effective $\mathrm{P} / \mathrm{O}$ ratios, however, remained constant over the investigated temperature range at $1.52 \pm 0.02$ with succinate as substrate (Fig. 4b). 

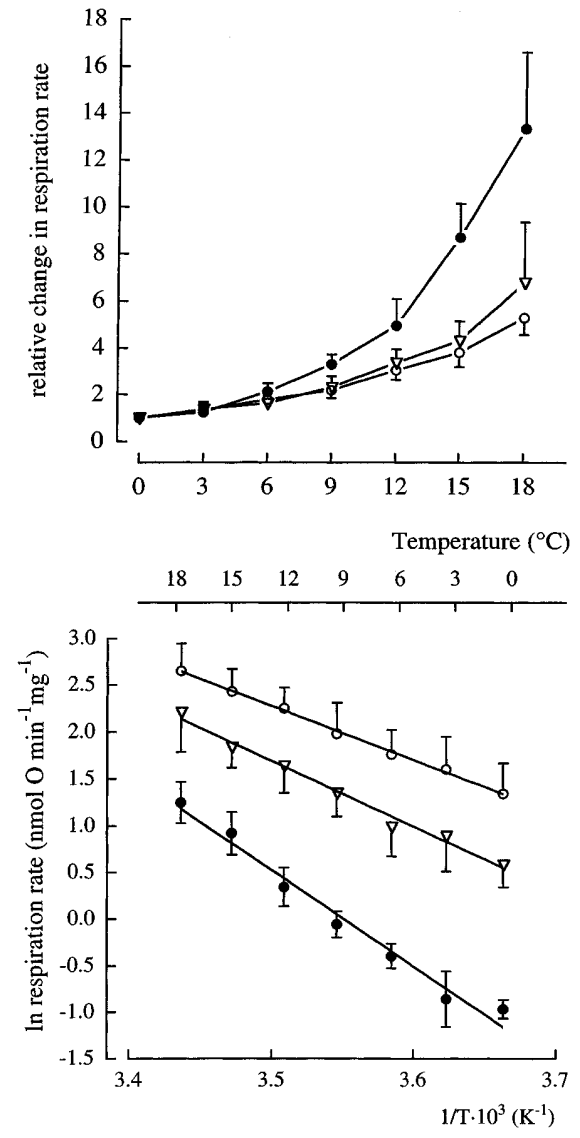

Fig. 3A, B Temperature dependence of the respiration rates in liver mitochondria from $L$. nudifrons. Open circles State 3 respiration; open triangles state 3 respiration in the presence of rotenone; filled circles state $4_{\text {ol }}$ A relative respiration rates. B Arrhenius plots. (Means $\pm \mathrm{SD}, n=5$ )

\section{$\mathrm{NADP}^{+}$-dependent IDH}

$\mathrm{NADP}^{+}$-dependent IDH was determined in the mitochondrial suspension and showed a specific activity of $0.43 \pm 0.32 \mathrm{mU} \mathrm{mg}^{-1}$ mitochondrial protein or $15.5 \pm 4.2 \mathrm{mU} \mathrm{g}^{-1}$ fresh weight liver tissue at $0{ }^{\circ} \mathrm{C}$ and

Table 1 Thermal sensitivity of mitochondrial respiration and isocitrate activity in liver mitochondria of Lepidonotothen nudifrons. All values are calculated for the temperature range $0-15^{\circ} \mathrm{C}$ or as given in parenthesis. (Means $\pm \mathrm{SD}, n=5$ for mitochondrial respiration, $n=4$ for enzyme activities)

\begin{tabular}{lcc}
\hline & $Q_{10}$ & $\begin{array}{c}\text { Arrhenius activation } \\
\text { energy }\left(\mathrm{kJ} \mathrm{mol}^{-1}\right)\end{array}$ \\
\hline $\begin{array}{l}\text { Mitochondrial respiration } \\
\text { State 3 }\end{array}$ & $2.43 \pm 0.26$ & $47.5 \pm 6.5$ \\
State 3 + rotenone & $2.63 \pm 0.35$ & $58.5 \pm 8.8$ \\
State 4 + oligomycin & $4.21 \pm 0.46$ & $92.5 \pm 4.9$ \\
Enzyme activity & & \\
NADP ${ }^{+}$isocitrate & $4.08 \pm 0.42$ & $91.4 \pm 4.6$ \\
dehydrogenase & $\left(0-15^{\circ} \mathrm{C}\right)$ & $\left(0-15^{\circ} \mathrm{C}\right)$ \\
& $3.19 \pm 0.16$ & $69.1 \pm 3.1$ \\
& $\left(15-30^{\circ} \mathrm{C}\right)$ & $\left(15-30^{\circ} \mathrm{C}\right)$ \\
\hline
\end{tabular}
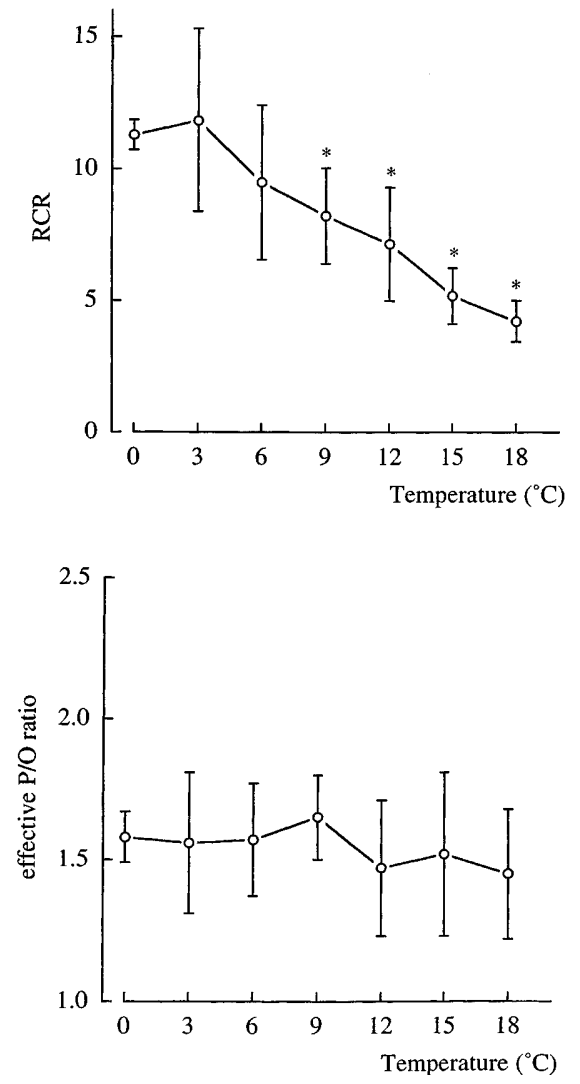

Fig. 4A, B Temperature effects on the function of the liver mitochondria from L. nudifrons. A Respiratory control ratios (RCR). B Effective $\mathrm{P} / \mathrm{O}$ ratios. * denotes a significant difference from the control values at $0{ }^{\circ} \mathrm{C}$. (Means $\pm \mathrm{SD}, n=5$ )

$10.2 \pm 5.6 \mathrm{mU} \mathrm{mg}^{-1}$ mitochondrial protein or $402.2 \pm 11.6 \mathrm{mU} \mathrm{g}^{-1}$ fresh weight liver tissue at $25^{\circ} \mathrm{C}$. Enzyme activity increased with assay temperature with a $Q_{10}$ of $4.08 \pm 0.42$ between $0{ }^{\circ} \mathrm{C}$ and $15^{\circ} \mathrm{C}$, which is in the same range as the $Q_{10}$ of state 4 respiration (Table 1). The Arrhenius plot shows a break at $15{ }^{\circ} \mathrm{C}$ above which enzyme activity increased less steeply with temperature (Fig. 5). The $E_{\mathrm{a}}$ in the physiological temperature range was $91.4 \pm 4.6 \mathrm{~kJ} \mathrm{~mol}^{-1}$.

\section{Discussion}

Respiratory properties of liver mitochondria from L. nudifrons

The maximal oxidative capacity of liver mitochondria of L. nudifrons was $3.68 \pm 1.19 \mathrm{nmol} \mathrm{O} \mathrm{min}^{-1} \mathrm{mg}^{-1}$ mitochondrial protein at $0{ }^{\circ} \mathrm{C}$ (with succinate as substrate) and $2.34 \pm 0.06 \mathrm{nmol} \mathrm{O} \mathrm{min}{ }^{-1} \mathrm{mg}^{-1}$ mitochondrial protein (with malate/pyruvate) which is lower than the values Johnston and co-workers found in mitochondria from red muscle of the same species $\left(28.6 \mathrm{nmol} \mathrm{O} \mathrm{min}^{-1} \mathrm{mg}^{-1}\right.$ mitochondrial protein at $-1{ }^{\circ} \mathrm{C}$ with pyruvate, Johnston et al. 1998). Maximal oxidative capacities from red muscle mitochondria of 

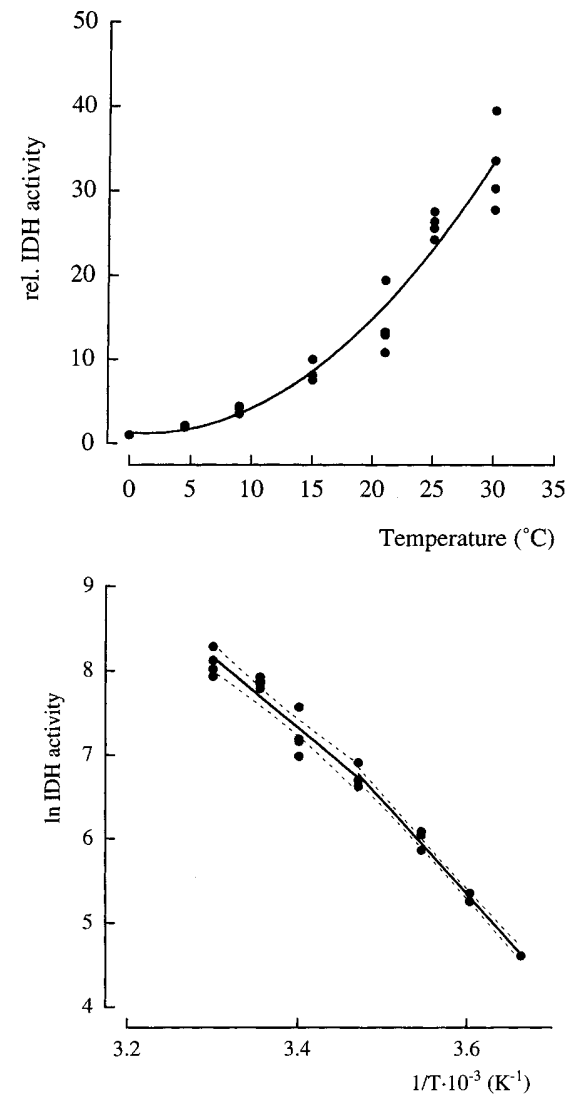

Fig. 5A, B Temperature dependence of the mitochondrial NADP ${ }^{+}$dependent isocitrate dehydrogenase from L. nudifrons. A Relative activity. B Arrhenius plot. (Means $\pm \mathrm{SD}, n=4$ )

other Notothenioids are also higher than those found in this study: $15.5 \mathrm{nmol} \mathrm{O} \mathrm{min}^{-1} \mathrm{mg}^{-1}$ mitochondrial protein for Notothenia coriiceps (at $-1{ }^{\circ} \mathrm{C}$; Johnston et al.

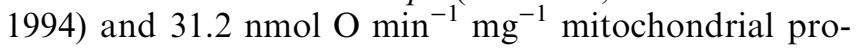
tein for Trematomus newnesi (at $-1{ }^{\circ} \mathrm{C}$; Johnston et al. 1998). The difference between Johnston's and our results may be due to the different origin of the mitochondria (liver versus red muscle). In general, liver mitochondria show lower respiration rates than mitochondria from red muscle (van den Thillart and Modderkolk 1978). Trout red muscle mitochondria respire about six times faster than mitochondria from trout liver (van den Thillart and Modderkolk 1978; Suarez and Hochachka 1981).

Mitochondria of Antarctic fish show only modest or no temperature compensation of their oxidative capacity when compared to temperate or tropical fish mitochondria (Johnston et al. 1994; Johnston et al. 1998). Therefore, the primary mechanism for enhancing the oxidative capacity of aerobic tissues in Antarctic fish is obviously not a rise in respiratory capacity of the single mitochondrion but an increase of mitochondrial density (Archer and Johnston 1991; Johnston et al. 1998).

Increasing mitochondrial densities, however, may be associated with enhanced metabolic costs for mitochondrial maintenance owing to dissipative proton fluxes across the inner mitochondrial membrane (Brand 1990; Pörtner et al. 1999c). Mitochondrial proton leakage has been shown to contribute significantly to the standard metabolic rate in different species (Brand 1990; Brand et al. 1994). In isolated rat hepatocytes $20-40 \%$ of the oxygen consumption is due to dissipative proton fluxes. Lizard hepatocytes devote about $30 \%$ of their oxygen consumption to proton leakage and in rat skeletal muscle a percentage as high as $52 \%$ has been estimated (Brand et al. 1994). These values show that mitochondrial proton leakage is also an important process in ectothermic organisms.

We determined the proton leak of liver mitochondria of $L$. nudifrons by the addition of saturating amounts of oligomycin which inhibits mitochondrial ATP synthase (Brand 1990). Inhibition of the ATP synthase, however, will increase the mitochondrial membrane potential and, therefore, the potential dependent proton leak (Brand 1990). The determined rates of proton leak must, therefore, be regarded as maximal estimates. In vivo values depend on the proton motive force under physiological conditions, which will presumably be somewhat lower than during state $4_{\mathrm{ol}}$. The strong influence of the membrane potential complicates a meaningful comparison of proton leakage rates between species. Comparisons in terms of the physical properties of the inner mitochondrial membranes should certainly be carried out at the same membrane potential. Comparisons of the physiological relevance of proton leakage, however, should be made at the respective in vivo membrane potential of the investigated species during resting conditions. Since these values are rarely available, we will compare state $4_{\mathrm{ol}}$ respiration rates with untitrated membrane potentials, which are assumed to be close to in vivo resting values. This is legitimate assumption since mitochondrial phosphorylation rates of resting cells are only $1-3 \%$ of the maximal value (state 3 ), indicating that state 4 respiration is close to in vivo resting conditions (Moyes et al. 1992).

The non-phosphorylating respiration rate (state $4_{\mathrm{ol}}$ ) of liver mitochondria of L. nudifrons was $0.38 \pm 0.04 \mathrm{nmol} \mathrm{O} \mathrm{min}^{-1} \mathrm{mg}^{-1}$ mitochondrial protein which is only $10.2 \%$ of state 3 respiration. In mitochondria of the Antarctic clam Laternula elliptica, a similar state $4_{\mathrm{ol}}$ respiration rate of $0.38 \pm 0.12 \mathrm{nmol}$ $\mathrm{O} \mathrm{min}^{-1} \mathrm{mg}^{-1}$ mitochondrial protein has been determined which amounts to $18.1 \%$ of state 3 respiration (Pörtner et al. 1999b). To our knowledge no other data exist on the proton leakage in ectothermic vertebrates at low temperatures. Brand and coworkers (1991) determined a value of $35.1 \mathrm{nmol} \mathrm{O} \mathrm{min}{ }^{-1} \mathrm{mg}^{-1}$ mitochondrial protein in lizard mitochondria at $37^{\circ} \mathrm{C}$, which is about $30 \%$ of the state 3 respiration of these mitochondria. A relatively low proton leakage of the mitochondria of L. nudifrons is also revealed by high respiratory control ratios (state 3 respiration/state 4 respiration in the presence of oligomycin) of $11.3 \pm 0.6$. This is higher than any RCR of liver mitochondria so far reported in the literature. Our data suggest that proton leakiness may be lower in mitochondria from Antarctic fish than in temperate fish mitochondria, but additional 
experimental evidence is still required to prove this hypothesis.

Thermal effects on mitochondrial respiration

State 3 respiration was dependent on temperature with a $Q_{10}$ of $2.43 \pm 0.26$ (without rotenone) or $2.63 \pm 0.35$ (in the presence of rotenone). This is in the range of values found for mitochondria from frog skeletal muscle (1.97-2.50; Pye 1973) and from short-horned sculpin (2.47-3.37; Guderley and Johnston 1996). $E_{\mathrm{a}}$ values over a wide temperature range (Pye 1970; El-Wadawi and Bowler 1995). The high $Q_{10}$ of about 4 observed in this study hints at the enzymatic catalysis of proton movement over the mitochondrial membrane. Investigations of Brookes and coworkers (1997) also suggest that proteins are involved in mitochondrial proton leakage. In protein-free liposomes they found only $5 \%$ of the leakage rates observed in intact mitochondria. Recently, Sazanow and Jackson (1994) proposed the existence of a substrate cycle in the mitochondrial matrix which is coupled to the dissipation of the mitochondrial proton gradient by the $\mathrm{H}^{+}$-transhydrogenase:

$$
\begin{gathered}
\text { isocitrate }+\mathrm{NAD}^{+} \underset{\mathrm{NAD} \text {-dependent IDH }}{\longrightarrow} \text { 2-oxoglutarate }+\mathrm{NADH}+\mathrm{CO}_{2} \\
\text { 2-oxoglutarate }+\mathrm{NADPH}+\mathrm{CO}_{2} \stackrel{\text { NADP-dependent IDH }}{\longrightarrow} \text { isocitrate }+\mathrm{NADP}^{+} \\
\mathrm{NADH}+\mathrm{NADP}^{+}+\mathrm{H}_{(\text {out })}^{+} \stackrel{\text { transhydrogenase }}{\longrightarrow} \mathrm{NAD}^{+}+\mathrm{NADPH}+\mathrm{H}_{(\text {in })}^{+}
\end{gathered}
$$

$\left(58.5 \mathrm{~kJ} \mathrm{~mol}^{-1}\right.$ and $47.5 \mathrm{~kJ} \mathrm{~mol}^{-1}$ with and without rotenone) are also in the range of values found in temperate fish: $34.8 \mathrm{~kJ} \mathrm{~mol}^{-1}$ and $51.1 \mathrm{~kJ} \mathrm{~mol}^{-1}$ for succinate oxidation in liver mitochondria from trout and catfish, respectively (Lyons and Raison 1970) and 55.4$68.9 \mathrm{~kJ} \mathrm{~mol}^{-1}$ for oxidation of pyruvate or palmitoyl carnitine in red muscle mitochondria from short-horned sculpin (Guderley and Johnston 1996). Apparently, the mitochondria of $L$. nudifrons do not show low $E_{\mathrm{a}}$ values compared to temperate species as has been proposed by Dahlhoff and co-workers (1991).

The Arrhenius plot of state 3 respiration (Fig. 3b) showed no break, indicating no phase transition of the inner mitochondrial membrane, and no heat inactivation of the enzymes involved in state 3 respiration between $0{ }^{\circ} \mathrm{C}$ and $15{ }^{\circ} \mathrm{C}$. In the Antarctic Notothenioid Trematomus bernacchii, a break in state 3 respiration was observed at $20^{\circ} \mathrm{C}$ (Weinstein and Somero 1998), which is beyond the temperature range investigated in this study. In contrast to the investigated fish mitochondria, mitochondria from the Antarctic clam Laternula elliptica show an Arrhenius break at temperatures as low as $9{ }^{\circ} \mathrm{C}$ (Pörtner et al. 1999b). This supports our hypothesis that Antarctic vertebrates are more tolerant towards high temperatures than Antarctic invertebrates.

Surprisingly, proton leakage of the mitochondria of L. nudifrons increased strongly with temperature, showing a $Q_{10}$ of 4.21. In the Antarctic clam Laternula elliptica proton leakage increased with temperature with a $Q_{10}$ of 4.1 (Pörtner et al. 1999b). These are exceptionally high values. If proton leakage was only brought about by diffusive proton movements a low $Q_{10}$ close to unity would be expected (Ellory and Hall 1987). In many ectothermic organisms, state 4 respiration exhibits low sensitivity to temperature changes (Lyons and Raison 1970; Almeida et al. 1994), with $Q_{10}$ values of 1.33-2.13
Proton leakage may at least partly be due to IDH substrate cycling. If this is the case, the high thermal sensitivity of proton leakage observed in the two investigated Antarctic species must be due to high thermal sensitivity of the enzymes taking part in this cycle. We have investigated the thermal sensitivity of one of the involved enzymes, the $\mathrm{NADP}^{+}$-dependent IDH from the liver tissue of $L$. nudifrons.

\section{Mitochondrial $\mathrm{NADP}^{+}$-dependent IDH}

IDH activity increased strongly with temperature (Fig. 5). The Arrhenius plot shows a break at $15^{\circ} \mathrm{C}$ with an $E_{\mathrm{a}}$ of $91.4 \mathrm{~kJ} \mathrm{~mol}^{-1}$ between $0{ }^{\circ} \mathrm{C}$ and $15^{\circ} \mathrm{C}$. Interestingly, this value is equal to the activation energy of state 4 respiration $\left(92.5 \mathrm{~kJ} \mathrm{~mol}^{-1}\right)$ which favours the assumption that mitochondrial proton leakage is linked to the substrate cycle involving NADP-dependent IDH.

Mitochondrial IDHs from temperate eurythermal ectotherms generally show lower $E_{\mathrm{a}}$ values than those from stenothermal polar or deep sea organisms: $E_{\mathrm{a}}$ values for NADP-dependent IDH were $55.2 \mathrm{~kJ} \mathrm{~mol}^{-1}$ in killifish Fundulus heteroclitus (Gonzales-Villasenor and Powers 1986), $76.3-78.4 \mathrm{~kJ} \mathrm{~mol}^{-1}$ in rainbow trout (Moon and Hochachka 1971) and $55 \mathrm{~kJ} \mathrm{~mol}^{-1}$ in temperate populations of the polychaete Arenicola marina (Pörtner et al. 1999c). These values are low compared to the values found in stenothermal species $\left(91.4 \mathrm{~kJ} \mathrm{~mol}^{-1}\right.$ in L. nudifrons, $138 \mathrm{~kJ} \mathrm{~mol}^{-1}$ in the Antarctic clam Laternula elliptica (Pörtner et al. 1999b) and $184.5 \mathrm{~kJ} \mathrm{~mol}^{-1}$ in the deep-sea fish Antimora rostrata (Moon and Storey 1975)). The low activation energies of $\mathrm{NADP}^{+}$-dependent IDH from eurythermal animals are in line with the low temperature dependency of proton leakage rates in mitochondria from eurythermal species (see below). 
Physiological implications

Our data on thermal effects on mitochondrial function reveal that elevated temperatures up to and even beyond the lethal limit of L. nudifrons do not impair oxidative mitochondrial metabolism. The discrepancy between the lethal temperature $\left(9^{\circ} \mathrm{C}\right)$ and the Arrhenius break temperature (ABT) of mitochondrial respiration $\left(>15^{\circ} \mathrm{C}\right)$, suggests that the onset of anaerobic metabolism at high temperatures, which is observed in ectothermic organisms, is obviously not due to mitochondrial dysfunction. A similar discrepancy between ABT of state 3 respiration and the onset of anaerobic metabolism $\left(T_{\mathrm{c}}\right)$ was observed in the Antarctic clam Laternula elliptica $\left(\mathrm{ABT}=9{ }^{\circ} \mathrm{C}, T_{\mathrm{c}}=3-6{ }^{\circ} \mathrm{C}\right.$; Pörtner et al. 1999b). However, in this species both ABT and $T_{\mathrm{c}}$ are shifted to a lower temperature range compared to $L$. nudifrons.

The differential thermal sensitivity of proton leakage and oxidative phosphorylation observed in the liver mitochondria of L. nudifrons leads to a decrease of the RCR with temperature. Temperature-induced uncoupling is known in mammalian mitochondria (Brooks et al. 1971; Luvisetto et al. 1992), but is usually not observed in mitochondria from ectothermic organisms. RCR values remain fairly constant in mitochondria from frog, trout, carp, goldfish and short-horned sculpin over a wide temperature range (Pye 1973; van den Thillart and Modderkolk 1978; Moyes et al. 1988; Blier and Guderley 1993; Guderley and Johnston 1996). Also, in the Antarctic Nototheniod Trematomus bernachii, RCR values remain constant up to a temperature of $18^{\circ} \mathrm{C}$. Mitchondria of the Antarctic clam Laternula elliptica remain coupled up to $9{ }^{\circ} \mathrm{C}$. These data indicate that the progressive uncoupling of mitochondria at slightly elevated temperatures, as it is observed in L. nudifrons, may not be typical for all stenothermal species.

The progressive uncoupling with increasing temperature leads to a decreased efficiency of the mitochondrial oxidation. This is, however, not reflected in lower effective $\mathrm{P} / \mathrm{O}$ ratios during state 3 respiration. $\mathrm{P} / \mathrm{O}$ ratios constantly remain close to 1.5 , which is in the range of values determined in succinate oxidising mitochondria from temperate fish (e.g. Suarez and Hochachka 1981; Bagarinao and Vetter 1990). The $\mathrm{P} / \mathrm{O}$ ratios were measured under non-physiological conditions during maximal phosphorylation when the proton motive force is low and proton leak virtually disappears (Brand 1990). However, at intermediate phosphorylation rates as they occur in vivo proton leak contributes significantly to oxygen consumption (Brand et al. 1994). It can be expected that under in vivo conditions, the phosphorylation efficiency of liver mitochondria from L. nudifrons decreases with increasing temperature. The efficiency of oxidative phosphorylation may be one of the processes limiting the survival of these organisms at high temperatures. The temperature dependence of ventilation (Fig. 1) may constrain the delivery of oxygen to the mitochondria. If the limited amount of oxygen that is available at high temperatures is then less efficiently used in the respiratory chain, the animal may be unable to produce sufficient amounts of ATP by aerobic means, which leads to the onset of anaerobic metabolism and eventually to death at temperatures of about $8-9{ }^{\circ} \mathrm{C}$.

Acknowledgements We are grateful to A. Chapman, R. Wood and S. Dunkerley for the supply of fish and we thank S. Leighton for excellent technical support during our stay at Rothera base. The experiments comply with the German guidelines of animal care.

\section{References}

Almeida VMF, Buck LT, Hochachka PW (1994) Substrate and acute temperature effects on turtle heart and liver mitochondria. Am J Physiol 266: R858-R862

Alp RP, Newshole EA, Zammit VA (1976) Activities of citrate synthetase and $\mathrm{NAD}^{+}$-linked and $\mathrm{NADP}^{+}$-linked isocitrate dehydrogenase in muscle form vertebrates and invertebrates. Biochem J 154: 689-700

Archer SD, Johnston IA (1991) Density of cristae and distribution of mitochondria in the slow muscle fibers of Antarctic fish. Physiol Zool 64: 242-258

Bagarinao T, Vetter RD (1990) Oxidative detoxification of sulfide by mitochondria of the California killifish Fundulus parvipinnis and the speckled sanddab Citharichthys stigmaeus. J Comp Physiol B160: 519-527

Blier PU, Guderley HE (1993) Mitochondrial activity in rainbow trout red muscle: the effect of temperature on the ADPdependence of ATP synthesis. J Exp Biol 176: 145-157

Brand MD (1990) The contribution of the leak of protons across the mitochondrial inner membrane to standard metabolic rate. J Theor Biol 145: 267-286

Brand MD, Courture P, Else PE, Withers KW, Hulbert AJ (1991) Evolution of energy metabolism. Biochem J 275: 81-86

Brand MD, Chien L-F, Ainscow EK, Rolfe DFS, Porter RK (1994) The cause and functions of mitochondrial proton leak. Biochim Biophys Acta 1187: 132-139

Brookes PS, Rolfe DFS, Brand MD (1997) The proton permeability of liposomes made from mitochondrial inner membrane pospholipids: comparison with intact mitchondria. J Membr Biol 155: 167-173

Brooks GA, Hittelman JA, Faulkner JA, Beyer RE (1971) Temperature, skeletal muscle, mitochondrial function and oxygen debt. Am J Physiol 220: 1053-1059

Clarke A (1991) What is cold adaptation and how should we measure it? Am Zool 31: 81-92

Crockett EL, Sidell BD (1990) Some pathways are cold adapted in Antarctic fishes. Physiol Zool 63: 472-488

Dahlhoff E, O'Brian J, Somero GN, Vetter RD (1991) Temperature effects on mitochondria from hydrothermal vent invertebrates: evidence for adaptation to elevated and variable habitat temperatures. Physiol Zool 64: 1490-1508

Dijk PLM van, Hardewig I, Pörtner HO (1998) Exercise in the cold: high energy turn over in Antarctic fish. In: Prisco G di, Pisano E, Clarke A (eds). Fishes of Antarctica. A biological overview. Springer, Berlin Heidelberg New York, pp 225-236

Dijk PLM van, Tesch C, Hardewig I, Pörtner HO (1999). Physiological disturbances at critically high temperatures. A comparison between stenothermal Antarctic, and eurythermal temperate eelpouts (Zoarcidae). J Exp Biol (In press)

El-Wadawi R, Bowler K (1995) The development of thermotolerance protects bowfly flight muscle mitochondrial function from heat damage. J Exp Biol 198: 2413-2421

Ellory JC, Hall AC (1987) Temperature effects on red cell membrane transport processes. In: Bowler K, Fuller BJ (eds) 
Temperature and animal cells. Symp Soc Exp Biol, vol 21, pp 53-66 Company of Biologists, Cambridge

Gonzalez-Villasenor LI, Powers DA (1986) A multilocus system for studying tissue and subcellular specialization. J Biol Chem 261: 11471-11477

Guderley H, Johnston IA (1996) Plasticity of fish muscle mitochondria with thermal acclimation. J Exp Biol 199: 1311-1317

Johnston IA, Guderley H, Franklin CE, Crockford T, Kamunde C (1994) Are mitochondria subject to evolutionary temperature adaptation? J Exp Biol 195: 293-306

Johnston IA, Calvo J, Guderley H, Fernandez D, Palmer L (1998) Latitudinal variation in the abundance and oxidative capacities of muscle mitochondria in perciform fishes. J Exp Biol 201: $1-12$

Luvisetto S, Schmehl I, Intravaia E, Conti E, Azzone GF (1992) Mechanism of loss of thermodynamic control in mitochondria due to hyperthyroidism and temperature. J Biol Chem 267: $15348-15355$

Lyons JM, Raison JK (1970) A temperature-induced transition in mitochondrial oxidation: contrasts between cold and warmblooded animals. Comp Biochem Physiol 37: 405-411

Moon TW, Hochachka PW (1971) Temperature and enzyme activity in poikilotherms: isocitrate dehydrogenases in rainbow trout liver. Biochem J 123: 695-705

Moon TW, Storey KB (1975) The effects of temperature and hydrostatic pressure on enzymes of an abyssal fish, Antimora rostrata: liver NADP-linked isocitrate dehydrogenase. Comp Biochem Physiol B52: 51-57

Moyes CD, Buck LT, Hochachka PW (1988) Temperature effects on $\mathrm{pH}$ of mitochondria isolated from carp red muscle. Am J Physiol 254: R611-R615

Moyes CD, Schulte PM, Hochachka PW (1992) Recovery metabolism of trout white muscle: role of mitochondria. Am J Physiol 262: R295-R304

Peck LS (1989) Temperature and basal metabolism of two Antarctic marine herbivores. J Exp Mar Biol Ecol 125: 1-12

Pörtner HO, Peck LS, Zielinski S, Conway LZ (1999a) Intracellular $\mathrm{pH}$ and energy metabolism in the highly stenothermal Antarctic bivalve Limopsis marionensis as a function of ambient temperature. Polar Biol 22: 17-30
Pörtner HO, Hardewig I, Peck LS (1999b) Mitochondrial function and critical temperature in the Antarctic bivalve, Laternula elliptica. Comp Biochem Physiol (in press)

Pörtner HO, Dijk PLM van, Hardewig I, Sommer A (1999c) Levels of metabolic cold adaptation: trade-offs in eurythermal and stenothermal ectotherms. In: Davison W, Williams $\mathrm{CH}$ (eds) Anatrctic ecosystems: models for wider ecological understanding. Caxton, Christchurch (In press)

Pye V (1973) Acute temperature change and the oxidation rates of ectotherm mitochondria. In: Wieser W (ed) Effects of temperature on ectothermic organisms. Springer Berlin Heidelberg New York, pp 83-95

Sazanow LA, Jackson JB (1994) Proton-translocating transhydrogenase and NAD- and NADP-linked isocitrate dehydrogenases operate in a substrate cycle which contributes to fine regulation of the tricarboxylic acid cycle in mitochondria. FEBS Lett 344: 109-116

Somero GN, Vries AL de (1967) Temperature tolerance in some Antarctic fishes. Science 156: 257-258

Sommer A, Klein B, Pörtner HO (1997) Temperature induced anaerobiosis in two populations of the polychaete worm Arenicola marina. J Comp Physiol B167: 25-35

Suarez PK, Hochachka PW (1981) Preparation and properties of rainbow trout liver mitochondria. J Comp Physiol 143: 269-273

Thillart G van den, Modderkolk J (1978) The effect of acclimation temperature on the activation energies of state III respiration and the unsaturation of membrane lipids of goldfish mitochondria. Biochim Biophys Acta 510: 38-51

Weinstein RB, Somero GN (1998) Effects of temperature on mitochondrial function in the Antarctic fish Trematomus bernachii. J Comp Physiol 168B: 190-196

Wibom R, Lundin A, Hultman E (1990) A sensitive method for measuring ATP-formation in rat muscle mitochondria. Scand J Clin Lab Invest 50: 143-152

Yeager DP, Ultsch GR (1989) Physiological regulation and conformation: a BASIC program for the determination of critical points. Physiol Zool 62: 888-907

Communicated by G. Heldmaier 